\title{
PERAN SERTA KELUARGA DALAM KESELAMATAN PASIEN DI RUMAH SAKIT
}

\author{
Ade Herawati Sahputri \\ adehera92@gmail.com
}

\section{Latar Belakang}

Keselamatan Pasien adalah suatu sistem yang membuat asuhan pasien lebih aman, meliputi asesmen risiko, identifikasi dan pengelolaan risiko pasien, pelaporan dan analisis insiden, kemampuan belajar dari insiden dan tindak lanjutnya, serta implementasi solusi untuk meminimalkan timbulnya risiko dan mencegah terjadinya cedera yangdisebabkan oleh kesalahan akibat melaksanakan suatu tindakan atau tidak mengambil tindakan yang seharusnya diambil. ( Permenkes, 2011 )

Apabila berbicara tentang keselamatan pasien, maka selalu identik dan dikaitkan dengan fasilitas kesehatan yang merupakan sarana prasarana terjadinya pelayanan kesehatan. Salah satu fasilitas pelayanan kesehatan yang paling besar adalah rumah sakit. Rumah sakit merupakan sarana pelayanan kesehatan, tempat berkumpulnya orang sakit maupun sehat serta memungkinkan terjadinya pencemaran lingkungan dan gangguan kesehatan.

Berada di rumah sakit membuat kita tak luput dari trjadinya kecelakaan. Kita sering mendengar terjadinya kecelakaan yang menimpa pasien. Ada banyak penyebab kecelakaan dirumah sakit. Seperti tindakan yang kurang tepat dari petugas kesehatan. Kesalahan pemberian obat dll.

Tentu saja hal tersebut bukan kemauan pasien. Bisa saja terjadi karna petugas kesehatan tidak sengaja dikarenakan beban kerja yang berat sehingga mereka kelelahan. Tetapi kecelakaan merugikan yang dialami pasien bisa diminimalkan oleh adanya kehadiran keluarga pasien.

Kelurga merupakan unit terkecil yang sangat berpengaruh pada kesehatan keluarganya. Keluarga memegang peranan penting dalam keselamatan pasien. Seperti yang kita ketahui ada beberapa tugas keluarga diantaranya yaitu menjaga dan merawat kondisi anggota keluarga agar tetap dalam keadaan optimal dan produktif, memperthankan dan meningkatkan status mental, mengantisipasi adanya perubahan sosial dan ekonomi, memotivasi dan memfasilitasi untuk memenuhi kebutuhan spiritual (Darwinto, dkk 2013). Oleh karena itu, kelurga sangat berpengaruh sebagai sistem pendukung utama menjaga keselamatan keluarganya di rumah sakit. 


\section{Metode}

Metode yang digunakan dalam kajian ini adalah metode literature review yaitu metode dengan cara membaca dari berbagai sumber seperti jurnal online, skripsi, dan ebook serta membandingkan isi dari berbagai sumber yang dibaca dan menyimpulkan dalam hasil kajian yang didapatkan pada jurnal, skripsi, e-book tentang peran serta keluarga dalam keselamatan pasien di rumah sakit.

\section{Hasil}

Hasil yang saya dapatkan setelah membaca dan membandingkan jurnal, skripsi, dan ebook adalah Keselamatan pasien merupakan disiplin ilmu di sektor perawatan kesehatan yang menerapkan metode ilmu keselamatan menuju tujuan mencapai sistem penyampaian layanan kesehatan yang dapat dipercaya. Keselamatan pasien juga merupakan atribut sistem perawatan kesehatan; Ini meminimalkan kejadian dan dampak, dan memaksimalkan pemulihan dari efek samping.

Keselamatan pasien dan kualitas pasien adalah jantung dari penyampaian layanan kesehatan. Untuk setiap pasien, yang merawat, anggota keluarga dan profesional kesehatan, keselamatan sangat penting untuk penegakan diagnosa, tindakan kesehatan dan perawatan. Dokter, perawat dan semua orang yang bekerja di sistem kesehatan berkomitmen untuk merawat, membantu, menghibur dan merawat pasien dan memiliki keunggulan dalam penyediaan layanan kesehatan untuk semua orang yang membutuhkannya. Khususnya keluarga mempunyai peranan yang penting dalam menjaga keselamatan pasien saat berada dirumah sakit.

Keluarga merupakan unit pelayanan dasar di masyarakat yang juga merupakan perawat utama dalam anggota keluarga. Keluarga dipandang sebagai suatu sistem, dimana keluarga mempengaruhi seluruh keluarga dan sebaliknya keluarga mempengaruhi status kesehatan anggota keluarga yang lain (Friedman, 1998).

Dalam upaya peningkatan derajat kesehatan dan mengatasi masalah kesehatan anggota keluarganya, keluarga harus mampu melaksanakan fungsi perawatan kesehatan keluarga. Fungsi perawatan kesehatan keluarga dapat berfungsi dengan baik jika keluarga dapat melaksanakan tugas keluarga di bidang kesehatan dengan baik pula.

Kesanggupan keluarga melaksanakan fungsi perawatan kesehatan keluarga dapat dilihat dari lima tugas keluarga di bidang kesehatan yang dilaksanakan. Pelaksanaan lima tugas keluarga dibidang kesehatan tersebut meliputi mengenal masalah 
kesehatan keluarga, mengambil keputusan mengenai tindakan kesehatan yang tepat bagi keluarga, merawat keluarga yang mengalami gangguan kesehatan, memodifikasi lingkungan keluarga untuk menjamin kesehatan keluarga dan memanfaatkan fasilitas pelayanan kesehatan di sekitarnya bagi keluarga (Setyowati, 2008).

\section{Pembahasan}

Hampir setiap tindakan medik menyimpan potensi risiko. Banyaknya jenis obat, jenis pemeriksaan dan prosedur, serta jumlah pasien dan staf Rumah Sakit yang cukup besar, merupakan hal yang potensial bagi terjadinya kesalahan medis (medical errors). Menurut Institute of Medicine (1999), medical error didefinisikan sebagai: Artinya kesalahan medis The failure of a planned action to be completed as intended (i.e., error of execusion) or the use of a wrong plan to achieve an aim (i.e., error of planning). didefinisikan sebagai: suatu kegagalan tindakan medis yang telah direncanakan untuk diselesaikan tidak seperti yang diharapkan (yaitu kesalahan tindakan) atau perencanaan yang salah untuk mencapai suatu tujuan (yaitu kesalahan perencanaan). Kesalahan yang terjadi dalam proses asuhan medis ini akan mengakibatkan atau berpotensi mengakibatkan cedera pada pasien, bisa berupa Near Miss atau Adverse Event (Kejadian Tidak Diharapkan/KTD).

Near Miss atau Nyaris Cedera (NC) merupakan suatu kejadian akibat melaksanakan suatu tindakan (commission) atau tidak mengambil tindakan yang seharusnya diambil (omission), yang dapat mencederai pasien, tetapi cedera serius tidak terjadi, karena keberuntungan (misalnya,pasien terima suatu obat kontra indikasi tetapi tidak timbul reaksi obat), pencegahan (suatu obat dengan overdosis lethal akan diberikan, tetapi staf lain mengetahui dan membatalkannya sebelum obat diberikan), dan peringanan (suatu obat dengan overdosis lethal diberikan, diketahui secara dini lalu diberikan antidotenya).

Adverse Event atau Kejadian Tidak Diharapkan (KTD) merupakan suatu kejadian yang mengakibatkan cedera yang tidak diharapkan pada pasien karena suatu tindakan (commission) atau tidak mengambil tindakan yang seharusnya diambil (omission), dan bukan karena "underlying disease" atau kondisi pasien.

Kesalahan tersebut bisa terjadi dalam tahap diagnostik seperti kesalahan atau keterlambatan diagnosa, tidak menerapkan pemeriksaan yang sesuai, menggunakan cara pemeriksaan yang sudah tidak dipakai atau tidak bertindak atas hasil pemeriksaan 
atau observasi; tahap pengobatan seperti kesalahan pada prosedur pengobatan, pelaksanaan terapi, metode penggunaan obat, dan keterlambatan merespon hasil pemeriksaan asuhan yang tidak layak; tahap preventive seperti tidak memberikan terapi provilaktik serta monitor dan follow up yang tidak adekuat; atau pada hal teknis yang lain seperti kegagalan berkomunikasi, kegagalan alat atau system yang lain.

Dalam kenyataannya masalah medical error dalam sistem pelayanan kesehatan mencerminkan fenomena gunung es, karena yang terdeteksi umumnya adalah adverse event yang ditemukan secara kebetulan saja. Sebagian besar yang lain cenderung tidak dilaporkan, tidak dicatat, atau justru luput dari perhatian kita semua

Standar keselamatan pasien tersebut terdiri dari tujuh standar yaitu :

\section{Hak pasien}

2. Mendidik pasien dan keluarga

3. Keselamatan pasien dan kesinambungan pelayanan

4. Penggunaan metoda-metoda peningkatan kinerja untuk melakukan evaluasi dan program peningkatan keselamatan pasien

5. Peran kepemimpinan dalam meningkatkan keselamatan pasien
6. Mendidik staf tentang keselamatan pasien

7. Komunikasi merupakan kunci bagi staf untuk mencapai keselamatan pasien

Untuk poin nomor 2 Standarnya adalah fasilitas pelayanan kesehatan harus mendidik pasien dan keluarganya tentang kewajiban dan tanggung jawab pasien dalam asuhan pasien.Kriterianya adalah keselamatan dalam pemberian pelayanan dapketerlibatan pasien yang merupakan partner dalam proses pelayanan. Karena itu, di fasilitas pelayanan kesehatan harus ada sistem dan mekanisme mendidik pasien dan keluarganya tentang kewajiban dan tanggung jawab pasien dalam asuhan pasien.

Dengan pendidikan tersebut diharapkan pasien dan keluarga dapat:

a. Memberikan informasi yang benar, jelas, lengkap dan jujur

b. Mengetahui kewajiban dan tanggung jawab pasien dan keluarga

c. Mengajukan pertanyaan-pertanyaan untuk hal yang tidak dimengerti

d. Memahami dan menerima konsekuensi pelayanan

e. Mematuhi instruksi dan menghormati peraturan fasilitas pelayanan kesehatan 
f. Memperlihatkan sikap menghormati dan tenggang rasa

g. Memenuhi kewajiban finansial yang disepakati

Keluarga merupakan matriks dari perasaan beridentitas dari anggota-anggotanya merasa memiliki dan berbeda. Tugas utamanya adalah memelihara pertumbuhan psikososial anggota-anggotanya dan kesejahteraan selama hidupnya secara umum. Keluarga juga membantu pertumbuhan dan perkembangan anggotanya, mengambil keputusan untuk melakukan tindakan yang tepat, dan memberikan perawatan kepada anggota keluarga yang sakit (Effendy, 1998).

Tugas kesehatan keluarga merupakan cerminan dari kemampuan keluarga dalam mempertahankan dan meningkatkan status kesehatan keluarga. Keluarga memiliki fungsi dalam menjalankan perawatan kesehatan. Kesanggupan keluarga melaksanakan fungsi perawatan kesehatan keluarga dapat dilihat dari lima tugas keluarga di bidang kesehatan yang dilaksanakan. Pelaksanaan lima tugas keluarga dibidang kesehatan tersebut meliputi mengenal masalah kesehatan keluarga, mengambil keputusan mengenai tindakan kesehatan yang tepat bagi keluarga, merawat keluarga yang mengalami gangguan kesehatan, memodifikasi lingkungan keluarga untuk menjamin kesehatan keluarga dan memanfaatkan fasilitas pelayanan kesehatan di sekitarnya bagi keluarga (Setyowati, 2008).

Peran keluarga dalam merawat pasien adalah pemeliharaan kesehatan yaitu mempertahankan keadaan kesehatan klien lanjutan agar tetap memiliki produktivitas tinggi. Keluarga mempunyai peran kesehatan dalam merawat klien stroke lanjutan antara lain: Pertama, mengenal masalah kesehatan keluarga. Kedua, memutuskan tindakan kesehatan yang tepat bagi keluarga. Ketiga, merawat keluarga yang mengalami gangguan kesehatan. Keempat, memodifikasi lingkungan keluarga untuk menjamin kesehatan keluarga. Kelima, memanfaatkan fasilitas pelayanan kesehatan disekitar keluarga. Kelima hal tersebut menunjukkan bahwa keluarga berperan penting dalam proses penyembuhan kembali pada klien (Suprajitno, 2004

Peran keluarga dalam perawatan diantaranya yaitu menjaga dan merawat kondisi anggota keluarga agar tetap dalam keadaan optimal dan produktif, memperthankan dan meningkatkan status mental, mengantisipasi adanya perubahan sosial dan ekonomi, memotivasi dan memfasilitasi untuk memenuhi kebutuhan spiritual (Darwinto, dkk 2013).Peran 
keluarga sesuai dengan tuga-tugas keluarga dalam bidang kesehatan salah satunya adalah memberikan perawatan kepada anggota keluarga yang sakit dan yang tidak dapat membantu dirinya sendiri karena cacat atau usianya terlalu muda. Peran keluarga tersebut meliputi mengingatkan/memonitor waktu minum obat, mengontrol persediaan obat, mengantarkan penderita kontrol, memisahkan alat-alat penderita dengan anggota keluarga lain, meningkatkan kesehatan lingkungan penderita, dan pemenuhan kebutuhan psikologis agar penderita tidak merasa terisolir dalam lingkungannya (Friedman, 1998).

Setiap keluarga mempunyai pola tersendiri dalam mengatasi masalah yang dihadapi oleh anggota keluarga termasuk masalah kesehatan pada lansia. Terkadang keluarga menyatakan telah melakukan tugas dengan baik dan telah memenuhi kebutuhan lansia sebagai anggota keluarga. Namun harus disadari bahwa lansia dengan penurunan fungsi yang dialami akan mengalami banyak perubahan yang tentunya membutuhkan perlakuan yang berbeda atau perlakuan yang spesifik sesuai dengan kondisi yang dialami.

\section{Penutup}

Hal yang dapat saya simpulkan disini adalah kelurga memegang peranan yang sangat penting dalam keselamatan pasien di rumah sakit. Tugas kesehatan keluarga memiliki hubungan positif dan sangat kuat dengan tingkat kemandirian keluarga. Semakin baik keluarga dalam menjalankan tugas kesehatan keluarga, semakin baik juga tingkat kemandirian keluarga. Perawat perlu meningkatkan pengetahuan, sikap dan keterampilan keluarga dalam melaksanakan tugas kesehatan keluarga. Sumber-sumber pendukung dalam keluarga merupakan faktor yang meningkatkan kemandirian dalam keluarga, sehingga perawat perlu memaksimalkan potensi positif dalam keluarga

\section{Daftar Pustaka}

Afriyani, Intan. 2011. HUBUNGAN PERAN KELUARGA DALAM MERAWAT PASIEN STROKE LANJUTAN DENGAN KONSEP DIRI PENDERITA DI POLIKLINIK SYARAF RS PKU MUHAMMADIYAH

YOGYAKARTA. Skripsi. Tidak diterbitkan. PROGRAM STUDI ILMU KEPERAWATAN. SEKOLAH TINGGI ILMU KESEHATAN 'AISYIYAH : YOGYAKARTA

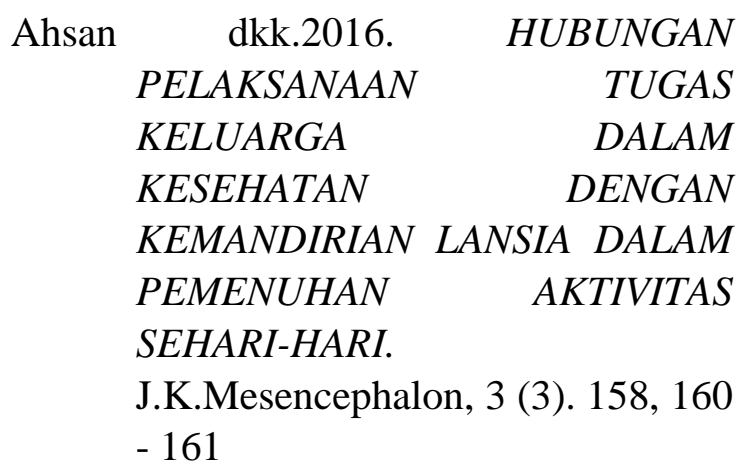


AYUNINGTIYAS, PUTRI YUNIAR. 2019. GAMBARAN PERAN KELUARGA DALAM MERAWAT ANGGOTA KELUARGA YANG MENGALAMI OSTEOARTRITIS DI DESA JETIS. Skripsi. Tidak diterbitkan. FAKULTAS ILMU KESEHATAN. UNIVERSITAS MUHAMMADIYAH SURAKARTA

Juniarti, Nanda Han dkk. 2018. PENERAPAN STANDAR KESELAMATAN PASIEN DI RUMAH SAKIT UMUM DAERAH PROVINSI NUSA TENGGARA $B A R A T$. Jurnal Kesehatan Poltekkes Ternate. 11 (2). 93-108

Kamil, Hajjul. Patient Safety. Idea Nursing Journal. 1(1). 1- 8

Kelen, Agnesia Priska L dkk. 2016. TUGAS KELUARGA DALAM PEMELIHARAAN KESEHATAN DENGAN MEKANISME KOPING LANSIA. Jurnal Care. 4 (1). hal. 60

Kertapati, Yoga. 2019. Tugas Kesehatan Keluarga dan Tingkat Kemandirian Keluarga di Wilayah Pesisir Kota Surabaya. Jurnal Ilmiah Keperawatan Stikes Hang Tuah Surabaya. 14 (1).1-8

Mulia, Madepan. 2018. PELAKSANAAN TUGAS KELUARGA DI BIDANG KESEHATAN: MENGENAL MASALAH HIPERTENSI TERHADAP KEJADIAN HIPERTENSI PADA LANSIA DI KELURAHAN TIMBANGAN KECAMATAN INDRALAYA UTARA KABUPATEN OGAN ILIR. ADI HUSADA NURSING JOURNAL . 4 (2). 19 - 21

Rejeki, Sri. 2016. Kesehatan dan Keselamatan Kerja. Kementerian
Kesehatan Republik Indonesia : Jakarta

Simamora, R. H. (2019). Buku ajar pelaksanaan identifikasi pasien. Uwais Inspirasi Indonesia.

Tutiany dkk. 2017. Manajemen Keselamatam Pasien. Kementerian Kesehatan Repblik Indonesia : Jakarta 